\title{
Location, Location, Location: How Electoral Opportunities Shape Women's Emergence as Candidates
}

\author{
Heather L. Ondercin (D) \\ Appalachian State University, Boone, NC, USA \\ Corresponding author. Email: hondercin@gmail.com
}

(Received 11 November 2019; revised 26 May 2021; accepted 3 August 2021; first published online 11 February 2022)

\begin{abstract}
Despite evidence that women win when they run for office, the number of women in the US House of Representatives has not increased substantially. I argue that women win when they run because women engage in strategic behavior by emerging in locations where they are most likely to win. While strategic behavior is a necessary condition for increasing women's representation in office, it is not a sufficient condition. Analyzing regularly scheduled elections between 1992 and 2014, I demonstrate that women engage in strategic behavior by emerging in elections where they are most likely to win. However, the electoral opportunities for women are far from "gender neutral" and are shaped by the parties. Democratic and Republican women are most likely to emerge as candidates in districts where they are likely to win the primary and general elections; however, Republican women face even more constrained electoral opportunities.
\end{abstract}

Keywords: women candidates, gender and elections, candidate emergence

Observers have noted that "When women run, they win" for over three decades (for examples, see Burrell 2014). Women have made modest gains in representation during this period, moving from 11 percent to 26.5 percent of members in the US Congress (Dittmar 2021). Consistent with these gains, recent studies conclude that women are not disadvantaged on Election Day (Burrell 2014; Dolan 2014). The uneven geography of where women run and win suggests that the electoral map may not be as "gender-neutral" as recent scholarship suggests. ${ }^{1}$ Indeed, research continues to find that voters hold and employ gender stereotypes when evaluating candidates (Bauer 2015; Ditonto 2017; Schneider and Bos 2014). Moreover, the process of candidate emergence is gendered (Fulton et al. 2006; Kanthak and Woon 2015; Preece and Stoddard 2015). Motivated by these observations, this article investigates whether women win when they run because women disproportionately run for office where they will win.

Drawing on research regarding the strategic calculations of candidates (Lazarus 2008; Stone and Maisel 2003) and the observation that some districts may be relatively friendly toward women candidates (Palmer and Simon 2010), I argue that women emerge in congressional districts where they have the best electoral opportunities. However, the quality of the gendered electoral opportunities means that even though women are behaving strategically, they may be emerging in locations where their likelihood of winning is fairly low. My argument is consistent with research demonstrating that women act strategically in their electoral calculations

\footnotetext{
${ }^{1}$ General-neutrality is used to describe elections where men or women are not systemically advantaged or disadvantaged, holding all else equal. Gender neutral does not mean that gender does not matter.

( ) The Author(s), 2022. Published by Cambridge University Press. This is an Open Access article, distributed under the terms of the Creative Commons Attribution licence (http://creativecommons.org/licenses/by/4.0/), which permits unrestricted re-use, distribution and reproduction, provided the original article is properly cited.
} 
(Burrell 2014; Fulton et al. 2006) and scholarship that challenges the gender-neutrality of elections (Barnes, Branton, and Cassese 2017; Fulton 2012; Pearson and McGhee 2013; Thomsen and Swers 2017). Moreover, Democratic women and Republican women face different challenges when running for elected office (Crowder-Meyer and Cooperman 2018; Sanbonmatsu 2010; Thomsen 2015). I argue that party affiliation further constrains women's electoral opportunities by shaping where Democratic women and Republican women emerge as candidates.

This article makes several theoretical and empirical contributions to the study of women and electoral politics. First, it examines where candidates emerge, not the decision of individual candidates. Shifting the unit of analysis from the individual to the congressional district uncovers important implications for our understanding of candidate emergence and electoral success. Research on the emergence of women candidates tends to compare women's behavior to men's behavior (Fulton 2012; Fulton et al. 2006; Lawless and Fox 2010) and focuses on psychological factors that structure women's political ambitions (Kanthak and Woon 2015; Preece and Stoddard 2015; Schneider et al. 2016). By examining broader contextual factors, this article demonstrates that the individual-level focus is insufficient to understand the multiple ways gender shapes electoral behavior.

My analyses test the assumption of the gender neutrality of elections. Claims of genderneutrality are reached by comparing men's and women's electoral fortunes after they have emerged as candidates. I argue that this outcome is not a function of gender neutrality, but results from women's nonrandom behavior. Gender may not play a significant role in particular elections because women have strategically entered races where their gender was not going to be a liability. Instead of offering a comparison between men and women, this article's focus on how context shapes women's behavior provides us with insights into the gendered nature of elections.

Looking at the relative emergence and success of women Democrats and women Republicans highlights how the parties shape the electoral opportunities and fortunes of women candidates (Crowder-Meyer and Lauderdale 2014; Palmer and Simon 2010; Thomsen 2015). My analyses demonstrate that Democratic women and Republican women weigh their electoral opportunities differently. Democratic women weigh the electoral opportunities in the primary and general elections about equally. Republican women appear to place more weight on their chances in the general election compared to the primary. Further, their electoral opportunities constrain both Democratic and Republican women; however, Republican women face an even more limited set of electoral opportunities. The different behavior and opportunities faced by Republican and Democratic women likely contribute to partisan differences in women's representation.

\section{Strategic Candidate Emergence and Success}

The path to elected office for any candidate consists of three stages: emergence, winning a primary, and winning the general election. Focusing on the final stage of the electoral process, all else equal, women do not seem to be disadvantaged on Election Day (see, for example, Burrell 2014; Dolan 2014). However, these findings do not mean that gender does not influence the electoral process (Dittmar 2015). Extensive research demonstrates that gender influences women's decisions to run for office (Bernhard, Shames, and Teele 2021; Kanthak and Woon 2015; Preece and Stoddard 2015; Schneider et al. 2016). I argue that candidate emergence and election outcomes are not independent; rather, where women emerge as a candidate will depend on the likelihood that a woman could win in that location. If women disproportionately choose to run where their gender will not have a negative effect on their ability to win, then strategic behavior will lead analyses of general election outcomes to conclude there is no difference in the performance of men or women candidates.

Why do women act strategically in selecting races where women are more likely to win? The basic calculus underlying strategic candidate emergence is that a potential candidate will run for elected office when the benefit of the candidate running and winning outweighs the 
cost (Lazarus 2008; Shames 2017; Stone and Maisel 2003). This calculus holds for both men and women. However, women may evaluate the costs and benefits of running for office differently than men (Shames 2017). Consistent with this, women candidates are more likely to take advantage of electoral opportunities that are lower in cost by running in open-seats, Democratic-leaning districts, and districts with other women-friendly characteristics (Hoffman, Palmer, and Gaddie 2001; Palmer and Simon 2010).

Previous research demonstrates women view running for office as more costly than men, which curtails the supply of women candidates. Women tend to express lower levels of ambition than similarly situated men (Fulton et al. 2006; Lawless and Fox 2010). One of the reasons for women's lower levels of ambition is the personal costs associated with familial responsibilities (Bernhard, Shames, and Teele 2021; Fulton et al. 2006). Carroll and Sanbonmatsu (2013, 45) explain that women's ambition may be relationally embedded, meaning "women's decision making about office holding is more likely to be influenced by the beliefs and reactions, both real and perceived, of other people and to involve considerations of how candidacy and office holding would affect the lives of others with whom the potential candidate has close relationships." Women tend to see themselves as less qualified to run for elected office than men (Lawless and Fox 2010). Evaluating one's qualifications for office suggests that one has both the strategic resources and personal skills necessary for a successful bid (Stone, Maisel, and Maestas 2004). If potential candidates view themselves as lacking these skills and resources, they will likely see a higher cost of running for elected office. As a result, the women who run for office are often more qualified than the men who run for office (Anzia and Berry 2011; Fulton 2012; Pearson and McGhee 2013).

Women also tend to be more risk averse than men, making women less likely to run for office (Schneider et al. 2016). Women are turned off by the electoral environment and are more sensitive to the opportunity structure and electoral considerations (Fulton et al. 2006). Women are more likely to express interest in serving on legislative bodies when the selection is made by lottery than when it requires running in elections (Kanthak and Woon 2015; Preece and Stoddard 2015). The ambition gap is partially a function of women viewing politics as conflictual and women's lower desire to engage in conflict, which shrinks when the role of the politician is reframed to focus on communal qualities, such as helping others (Schneider et al. 2016).

Finally, women incumbents are more likely to face quality challengers, and more candidates tend to emerge to run against women in primary elections (Lawless and Pearson 2008; Pearson and McGhee 2013). Due to this increased competition, women incumbents may face more costly elections. This heightened competition places many women at an electoral disadvantage relative to men (Barnes, Branton, and Cassese 2017; Pearson and McGhee 2013). While women often raise as much money as men (Burrell 2014), women candidates receive less return on their campaign spending than men (Crespin and Deitz 2010; Herrick 1996). As a result, women candidates may perceive the cost of elections differently than men, but the actual financial cost of running in elections also may be higher for women.

This variation in cost means women require a more substantial benefit and/or a higher probability of winning to emerge as candidates. In addition to gender shaping candidate emergence, multiple factors increase (or decrease) women candidates' electoral success. Central to our understanding of these processes is the work of Palmer and Simon (2010) on "womenfriendly" districts. Starting with the districts where women were successful between 1972 and 2000, Palmer and Simon identify what made these districts different from districts that did not elect women. These characteristics include: being solidly Democratic; being small in geographic size; being more urbanized; being located in the North rather than the South; and containing more minority ethnic, foreign-born, older, more-educated, and higher-income populations, and fewer blue-collar workers. Palmer and Simon's work takes an inductive approach, working backwards to identify the contextual factors that set districts where women win apart from those where women are not successful. This analysis provides a rich descriptive understanding 
of where women candidates are successful. I build on Palmer and Simon's work to provide a more systematic account of how contextual factors shape candidate emergence.

While the net numbers suggest that women candidates are not disadvantaged at the ballot box, analyses controlling for candidate quality and electoral circumstances find that women candidates are disadvantaged (Barnes, Branton, and Cassese 2017; Bauer 2020; Fulton 2012). An extensive body of research demonstrates the use and impact of gender stereotypes. Voters' expectations of politicians and women's roles do not significantly overlap, suggesting that women running for office are disadvantaged because voters do not assume they hold the basic qualities associated with elected officials (Schneider and Bos 2014). Voters view women and men candidates using sex-based issue and trait stereotypes (Bauer 2015; Ditonto 2017). Women candidates need to be viewed as having more qualifications to receive the same evaluations as men candidates (Bauer 2020). However, recent scholarship suggests that outside of the experimental setting, gender stereotypes and media coverage do not disadvantage women candidates (Dolan 2014; Hayes and Lawless 2015). This article helps reconcile these two findings by demonstrating the systemic nature of where women emerge as candidates.

It is useful to take a step back from our comparisons of men and women candidates and focus our attention on how the electoral opportunities for women vary across congressional districts in the United States. Examining how gendered electoral opportunities shape where women run for office allows for a better understanding of why strategic behavior on the part of women candidates has limited effects on women's representation despite the appearance of gender neutrality in election outcomes. Further, we can assess the gender neutrality of elections (or lack thereof) by bringing together information about gendered electoral opportunities and candidate emergence. First, I argue that the likelihood a woman can win the primary or general election in that location shapes whether women emerge as candidates. Strategic behavior on the part of potential women candidates would take into consideration traditional costs and benefits of running and how their gender may act as a liability. By taking into account the influence of gender on electoral outcomes, woman's strategic emergence means that women are running in locations where their gender will not be a liability.

Stone and Maisel (2003) stress that gaining a seat in the House of Representatives is a two-election process, requiring winning both the party's nomination and the general election. In their analysis, they find that as the partisanship of the district becomes more favorable for winning the general election, the likelihood of winning the primary election decreases. This finding suggests that candidates have to navigate a tricky path toward elected office. To maximize their chance of obtaining elected office, we would expect women candidates to emerge in districts where they are most likely to win both the party's nomination and the general election. Stone and Maisel (2003) find that district partisanship has a symmetrical effect, suggesting that equal weight is applied to the electoral opportunities at the primary and general election stages. Extrapolating from this finding, women candidates should equally weigh the electoral prospects in the primary and general elections.

Secondly, I argue that we should not take strategic behavior on the part of women candidates as evidence of the "gender neutrality" of elections. As strategic behavior may produce results that look like gender neutrality, we need to examine the quality of electoral opportunities available to women candidates. Women may run where they are most likely to win but still end up running in races where their chance of winning is relatively low. By assessing both the electoral opportunity and where women run, we can determine the "gender neutrality" of elections.

Finally, I expect the parties to shape both electoral opportunities and where women emerge as candidates. Smaller eligibility pools have resulted in women's underrepresentation in the Republican Party (Crowder-Meyer and Lauderdale 2014). Palmer and Simon (2010) find that there is a difference between districts that are "friendly" to Democratic women and districts that are "friendly" to Republican women. Therefore, it is important to explore patterns of Democratic and Republican women candidates emerging separately. Moreover, Democratic 
and Republican women have access to different donor networks and encounter different political cultures related to the importance of women's representation (Crowder-Meyer and Cooperman 2018; Thomsen and Swers 2017). The intersection of gender and party suggests that compared to women Democratic candidates, women Republican candidates will encounter more limited electoral opportunities (Thomsen 2015). However, despite differences in electoral prospects, I expect where Democratic women and Republican women emerge will still be tied to those electoral opportunities.

\section{Analyses}

I analyze the relationship between where women emerge as candidates and gendered electoral opportunities with data on all regularly scheduled elections for the US House of Representatives between 1992 and 2014. The unit of analysis is the congressional district. This unit of analysis makes it feasible to study where women candidates emerge across congressional districts and over multiple election cycles. Several studies of candidate emergence have used a potential candidate's perception of winning to study candidate emergence (Fulton et al. 2006). The potential candidate as the unit of analysis makes more personal assessments feasible. However, these studies' scopes are relatively limited due to the difficulty and cost of identifying and surveying potential candidates. Moreover, strategic behavior on the part of women candidates likely masks the influence of gender on electoral politics at the individual level.

Studies of candidate emergence highlight that potential candidates are not ignorant of the conditions and qualities that are seen as necessary for winning elected office (Fulton et al. 2006; Lawless and Fox 2010; Stone and Maisel 2003). As most candidates for the US House of Representatives are not political amateurs, they should have a feel for the factors included in the model to estimate candidate success. If political amateurs are entering the electoral arena without any information, then it should make the models estimated here less likely to find empirical relationships.

The analysis is carried out in two stages. The first stage estimates the variation in electoral opportunities. The second stage examines how where women candidates emerge is shaped by these electoral opportunities. I estimate three different specifications; the first examines the influence of winning the primary on where women emerge; the second looks at the influence of winning the general election on where women emerge; and the third specifies an interaction between winning the primary and winning the general election.

\section{Variation in Electoral Opportunities}

The first portion of the analysis assesses women candidates' electoral opportunities, measured as the probability of a woman winning the primary election and the probability of a woman winning the general election. These probabilities are generated from logit models. The first dependent variable identifies whether a woman candidate was successful in the primary election. It is coded 1 if a woman won the primary election and 0 if a woman did not win the primary election. The second dependent variable measures the success of a woman candidate in the general election, coded 1 if a woman won the general election and 0 if a woman did not win the general election. ${ }^{2}$

The goal of this analysis is not to explain the factors that lead to women candidates' success. Instead, the goal is to assess how likely a woman can win the primary election or win the general election in a congressional district. The models that produce the predicted probabilities include a set of variables that may increase (or decrease) the likelihood of a woman succeeding in that

\footnotetext{
${ }^{2}$ The specification for the model predicting the probability of a woman winning the primary is: $w_{\mathrm{it}}^{\text {primary }}=\beta X_{\mathrm{it}}+\delta D_{\mathrm{it}}+\epsilon_{\mathrm{it}}$. The specification for the model predicting the probability of a woman winning the general election is: $w_{\mathrm{it}}^{\text {general }}=\beta X_{\mathrm{it}}+\delta D_{\mathrm{it}}+\epsilon_{\mathrm{it}}$. Here, $\beta$ is a vector of coefficients estimated for the independent variables $X, \delta$ is a vector of coefficients for the time dummies $D, \epsilon$ is the error term, $i$ indexes the district, and $t$ indexes the year.
} 
congressional district given that a woman emerges as a candidate. Variables for incumbency, the partisan composition of the district, experience with women in elected office, and the characteristics that make a district women friendly are included in the model of a woman winning the primary election and the model of a woman winning the general election. ${ }^{3}$

A woman should be more likely to win when she is the incumbent or when there is no incumbent (Hoffman, Palmer, and Gaddie 2001). The presence of an incumbent and the incumbent's sex is accounted for with a pair of dummy variables: Woman incumbent is coded 1 if the incumbent is a woman and 0 otherwise; and Man incumbent is coded 1 if the incumbent is a man and 0 otherwise. The omitted category is an open-seat election.

The district's partisan composition should also influence the chance of a woman winning, with women more likely to win elections in Democratic-leaning districts (Palmer and Simon 2010). While we would generally expect Republicans to not do well in Democratic-leaning districts, these districts represent the best electoral opportunities for Republican women (Palmer and Simon 2010). Two different measures of the partisan leanings of the district are included: Democratic partisanship of the district and Democratic vote t $_{t-1}$.

Candidate sex is less likely to act as a liability in locations where women have previously held elected office (Ondercin and Welch 2005). We would also expect women to win in locations where there are potentially more qualified women candidates or a larger eligibility pool (Crowder-Meyer and Lauderdale 2014). Four different indicators are used to capture a district's experience with women officeholders. I include measures of the proportions of Democratic women in the state legislature and Republican women in the state legislature, and if women are serving in the US Senate or as governor. The percentage of women in the state legislature captures the eligibility pool.

The set of district characteristics Palmer and Simon (2010) identify as creating a womenfriendly district are included in the models: South, District size, Percentage foreign born, Relative median income, Percentage with four years of college, Percentage blue collar, Percentage Hispanic, Percentage black, and Percentage urban. Instead of creating an index based on these factors, each of these measures was included in the models to allow the effects to vary by party and election type.

Women candidates experience greater success under more open primary rules (Fiber-Ostrow 2012). As a result, the primary success models also include a set of dummy variables indicating the electoral rules governing the primary election, with open primaries as the omitted category. Women candidates are likely to experience greater competition (Barnes, Branton, and Cassese 2017; Lawless and Pearson 2008). In the models predicting success in the primary, measures of the number of candidates, the number of quality candidates, and the total amount of spending in the primary are included to control for the competitiveness of the election. The model of success in the general election includes measures of the spending by the Democratic and Republican candidates to control for competitiveness. Additionally, both models include dummy variables for the election year, with 1992 serving as the omitted year. These dummy variables control for any election-specific effects.

Tables A1, A2, and A3 in the Online Appendix report the results of the models of electoral success for women in the primary and general elections. The electoral opportunities for women candidates vary considerably across the United States. My discussion of these results does not focus on the influence of specific variables because the goal is not to explain what factors shape women's electoral success, but rather to assess the variation in these electoral opportunities. To illustrate this, Figure 1 presents the probability of a woman winning the primary election in 2014 (Panel A) and the probability of a woman winning the general election in 2014 (Panel B) for each congressional district. Darker areas of the map represent a higher probability of a woman winning the election.

\footnotetext{
${ }^{3}$ More detailed descriptions of how variables are measured can be found in the online data replication materials.
} 


\section{A. Probability of Winning Primary}

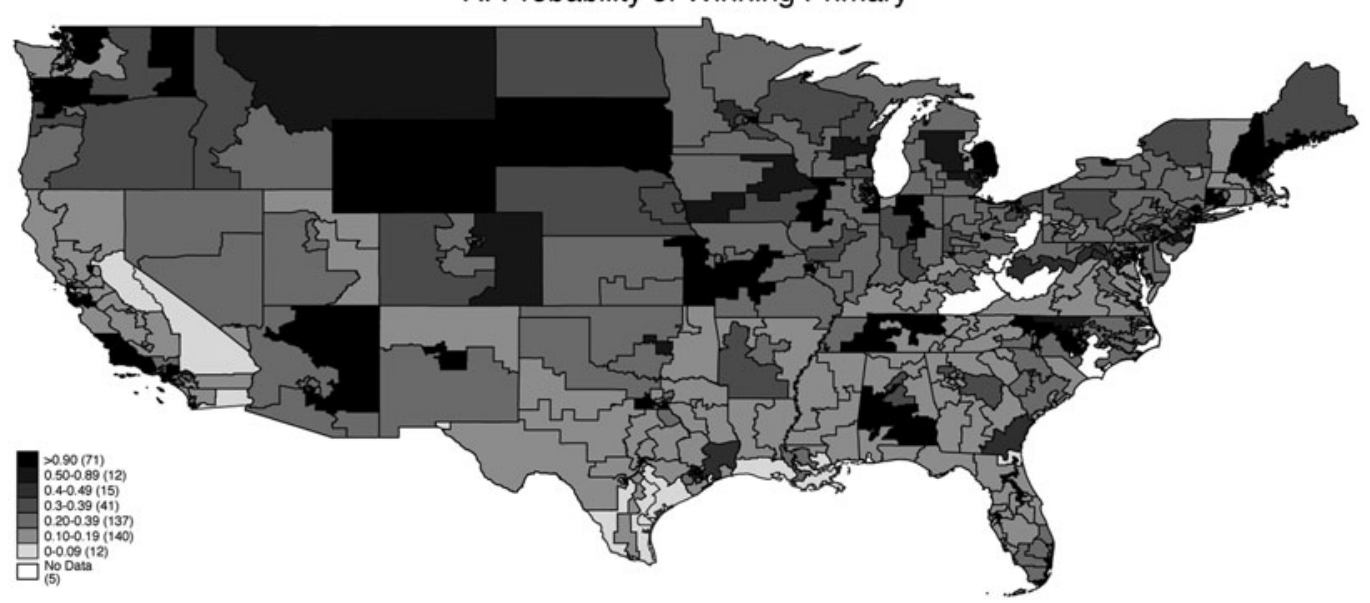

\section{B. Probability of Winning General}

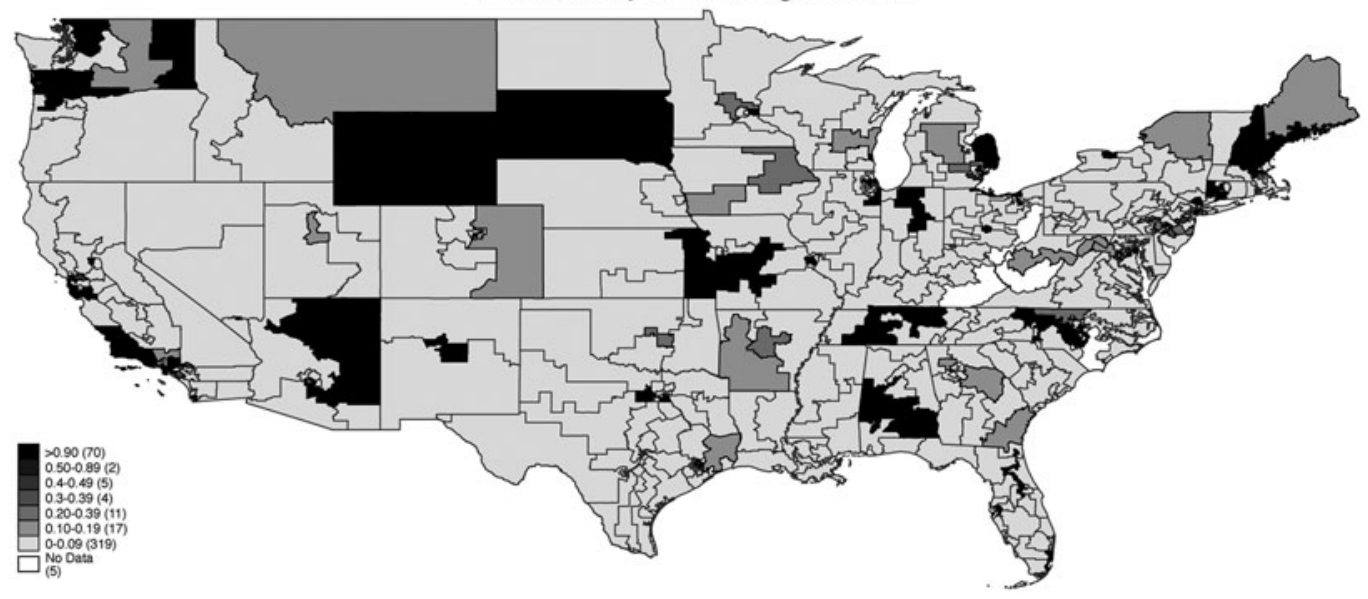

Figure 1. The probability of a woman winning the primary and general elections, 2014.

Three important patterns emerge from Figure 1. First, women have considerably more electoral opportunities in the primary than in the general elections. Second, there often is a considerable amount of variation within states. For example, in California, congressional districts range from electoral environments hostile to women candidates to districts representing some of the best opportunities for women candidates' success. Third, there are a set of districts where a woman's chance of winning is relatively high: 16 percent of the districts had a 0.99 probability of a woman winning the primary election. However, outside of those districts, the electoral opportunities of women candidates are much more limited: in 80 percent of the congressional districts, a woman's chance of winning was less than 0.50. The likelihood of a woman winning narrows even more when we consider the general election: 16 percent of the districts had a 0.91 or higher chance of a woman winning the general election, but 83 percent of the congressional districts have a probability of a woman winning the general election of less than 0.5 .

The year 2014 is the last of the analysis and represents some of the best electoral opportunities for women candidates. Maps for each election in the analysis, both pooled and broken down by party, can be found in the Online Appendix. Generally speaking, the electoral prospects of women increase over time. However, the maps by party illustrate the increasing difference 
Table 1. Percentage correctly predicted from models of candidate women success

\begin{tabular}{lr}
\hline & $\%$ \\
\hline Woman win primary & 84.67 \\
Women win general & 97.16 \\
Democratic woman wins primary & 86.67 \\
Democratic woman wins general & 97.62 \\
Republican woman wins primary & 91.53 \\
Republican woman wins general & 95.50 \\
\hline
\end{tabular}

between the electoral opportunities for Democratic women and Republican women, especially at the primary stage. The electoral opportunities increase for Democratic women but become more challenging for Republican women.

Before moving on to the analysis of how the electoral opportunities of women shape women's emergence as candidates, we need to consider how well these models explain where women are successful. The percentage correctly predicted is a standard used to assess how well logit models describe the data. Table 1 reports the percentage correctly predicted for each model of electoral success. Overall, the models perform quite well. The model with the lowest correct predictions still correctly estimates the success of women in the primary election 84.67 percent of the time.

\section{Candidate Emergence}

My second set of analyses uses the predicted probabilities produced from the success models discussed in the previous section to identify the electoral opportunities for women in a congressional district. The likelihood of winning the primary election and the likelihood of winning the general election are the central independent variables in the models of where women candidates emerge. The theoretical argument indicates that women should emerge when the probability of winning is relatively high. In order to avoid potential problems that could result from estimating both the probability of winning and emerging from the same observations, the predicted probabilities of a woman winning in the primary and general election are lagged by one election cycle. For example, the predicted probability of a woman winning the primary in 1992 is used when estimating the likelihood of a woman candidate emerging in 1994. Redistricting in 1992 and 2002 results in these two elections dropping from the analysis. The dependent variable in the emergence models is a dummy variable identifying women candidates emerging to run for elected office, coded 1 if a woman ran in a primary election in that congressional district and 0 if no woman ran in a primary election. ${ }^{4}$

The candidate emergence model includes a set of variables to control for information that would be readily available when potential candidates would be deciding to emerge. This model includes controls for incumbency, district partisanship, vote for the Democratic candidate in the previous election, Democratic women in the state legislature, Republican women in the state legislature, whether women are serving in the US Senate or as governor, the type of primary, and a set of district characteristics. ${ }^{5}$ The amount spent by the Democratic and Republican can-

\footnotetext{
${ }^{4}$ The specifications for the models predicting if a woman emerges as a candidate are: $Y_{\mathrm{it}}=\omega w_{\mathrm{it}-1}^{\text {primary }}+\beta X_{\mathrm{it}}+\delta D_{\mathrm{it}}+\epsilon_{\mathrm{it}}$ and $Y_{\mathrm{it}}=\omega w_{\mathrm{it}-1}^{\text {general }}+\beta X_{\mathrm{it}}+\delta D_{\mathrm{it}}+\epsilon_{\mathrm{it}}$. Here, $w$ is the probability of winning either the primary or general election that was estimated in the previous section. It should be noted that the probabilities of winning the primary or general election are lagged one election cycle when they are used to estimate the probability that a woman will emerge as a candidate. Also, $\omega$ is a coefficient estimated for $w_{\mathrm{it}-1}^{\text {primary }}$ or $w_{\mathrm{it}-1}^{\text {general }}, \beta$ is a vector of coefficients estimated for the independent variables $X, \delta$ is a vector of coefficients for the time dummies $D, \epsilon$ is the error term, $i$ indexes the districts, and $t$ indexes the year.

${ }^{5}$ These variable specifications are the same as in the winning equations, except for incumbency and competitiveness of elections. Incumbency is not disaggregated by sex.
} 
Table 2. Results for all candidates of a woman winning the primary, a woman winning the general, and a woman emerging as a candidate

\begin{tabular}{|c|c|c|c|}
\hline & $\begin{array}{l}\text { Emerge primary } \\
\text { (Primary) }\end{array}$ & $\begin{array}{l}\text { Emerge primary } \\
\text { (General) }\end{array}$ & $\begin{array}{c}\text { Emerge primary } \\
\text { (Interaction) }\end{array}$ \\
\hline $\operatorname{Pr}(\text { Win primary })_{t-1}$ & $\begin{array}{l}4.03^{\star \star \star} \\
(0.21)\end{array}$ & - & $\begin{array}{l}2.28^{\star \star \star} \\
(0.57)\end{array}$ \\
\hline $\operatorname{Pr}(\text { Win general })_{t-1}$ & - & $\begin{array}{l}3.59^{\star \star *} \\
(1.07)\end{array}$ & $\begin{array}{l}2.20^{\star \star \star} \\
(0.85)\end{array}$ \\
\hline Interaction & - & - & $\begin{array}{l}-0.52 \\
(0.85)\end{array}$ \\
\hline
\end{tabular}

Notes: Bootstrapped coefficients and standard errors. Full model includes the following controls: incumbent; Democratic partisanship; Democratic vote $_{t-1}$; woman senator; woman governor; percentage Democratic women in state legislature; percentage Republican women in state legislature; Democratic spending $t_{t-1}$; Republican spending $t_{t-1}$; type of primary dummies; percentage school-age children; percentage blue-collar workers; percentage four-year college graduates; percentage foreign born; percentage urban; relative income; land in square miles, percentage Hispanic; percentage black; South; and election dummies. ${ }^{\star} p<0.1 ;{ }^{\star \star} p<0.05 ;{ }^{\star \star \star} p<0.01$.

didates during the last election is added to these models. ${ }^{6}$ The data structure (congressional districts observed at multiple points in time) and modeling approach (including an estimate as an independent variable) could result in biased coefficients and standard errors. As a result, I report bootstrapped coefficients and standard errors. ${ }^{7}$

Table 2 reports the coefficients for the variables measuring electoral opportunities. ${ }^{8}$ Figure 2 illustrates the relationship between the lagged probability of a woman winning the primary and a woman emerging as a candidate (Panel A), and the lagged probability of a woman winning the general election and emerging as a candidate (Panel B). ${ }^{9}$ Predicted probabilities are plotted for open-seat elections (solid line) and non-open-seat elections (dashed line). As expected, the lagged probability of a woman winning the primary election is positively and significantly related to the probability that a woman candidate will emerge (Panel A). When there is an open seat, women are highly likely to throw their hat in the ring (Panel A, solid line). In districts where it is highly unlikely that a woman will win the primary $\left(\operatorname{Pr}\left(\right.\right.$ Win Primary $\left.\left.y_{t-1}\right)=0.02\right)$, women are likely to emerge as primary candidates about 61 percent of the time. The probability of a woman emerging as a candidate increases to 0.92 when the lagged probability of winning the primary election is just below 50 percent. When an incumbent is present (Panel $\mathrm{A}$, dotted line), a woman candidate is considerably less likely to emerge as a primary candidate. In districts where a woman has the lowest chance of winning, there is only about a 20 percent chance a woman will emerge as a candidate. When the lagged probability of a woman winning the primary election increases to just below 50 percent, the probability of a woman emerging as a candidate increases to about 0.73 .

Panel B reports the results for the relationship between the lagged probability of winning the general election and a woman candidate emerging. The solid line represents the probability of a woman candidate emerging in an open-seat election and the dotted line represents the probability of a woman emerging in a non-open-seat election. Similar to the relationships in primary

\footnotetext{
${ }^{6}$ These spending measures replace measures of district competitiveness that had been included when modeling success.

${ }^{7}$ The structure of the data suggests the possibility of unit effects due to correlations of the errors within congressional districts and states. The model includes multiple different district-level variables to directly account for these unit effects; however, this does not ensure that the errors are uncorrelated. Bootstrapping addresses the bias in the standard errors when the number of units in a cluster is small. Additionally, the probability of winning the primary or the general elections are estimated with errors associated with those estimates. If we do not account for this, our standard errors may once again be biased. Bootstrapping is one way to provide this adjustment to standard errors and is preferable to jackknife estimates (Cameron and Trivedi 2005).

${ }^{8}$ The full model results are reported in Table A1 in the Online Appendix.

${ }^{9}$ Two sets of predicted probabilities are reported: the predicted probabilities of a woman candidate emerging in an open seat (incumbency $=0$ ); and the predicted probabilities of a woman emerging when there is an incumbent (incumbent $=1$ ). The predicted probabilities of a woman emerging are generated with dummy variables at 0 and all other variables at their mean.
} 
Panel A: Emerging in the Primary Election

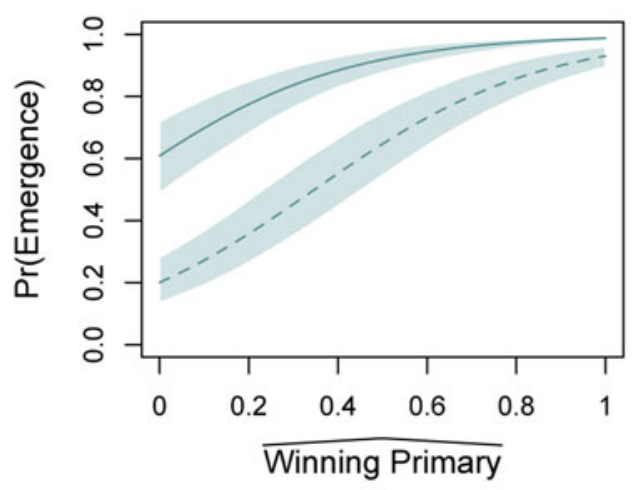

Panel C: Probability of Winning Primary

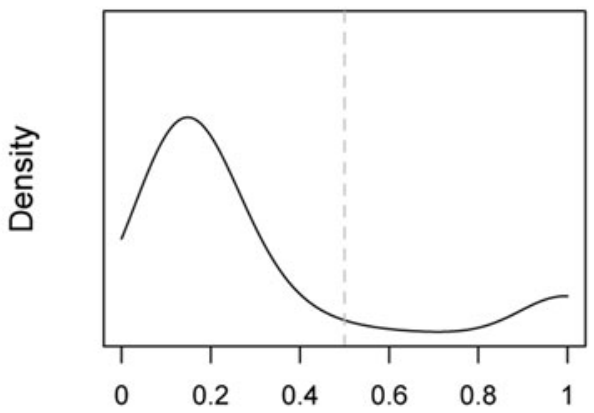

Panel B: Emerging in the Primary Election

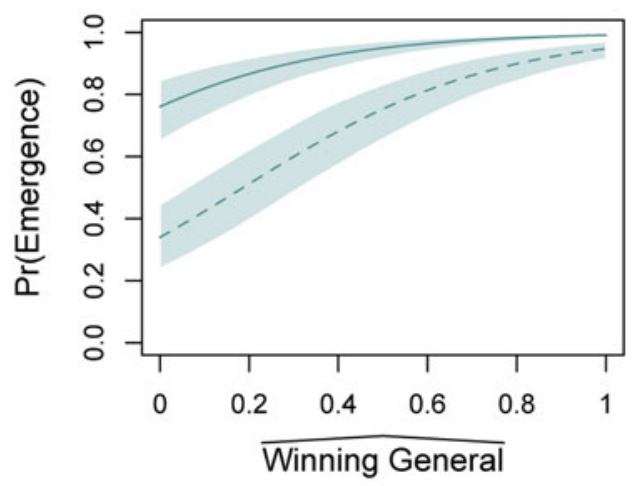

Panel D: Probability of Winning General

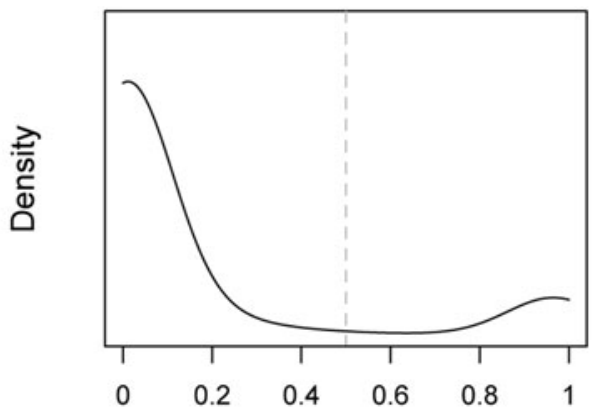

Figure 2. Predicted probabilities of a woman candidate emerging in a primary election.

elections, as the lagged probability of a woman winning the general election increases, the likelihood that a woman will emerge increases. In open-seat elections, even when the chance of a woman winning is at its lowest, the probability of a woman emerging as a candidate is 0.75 . When the probability of a woman winning the general election in the congressional district is just below 50 percent, there is a 95 percent probability of a woman emerging. When there is an incumbent present, in districts with a low probability of electing a woman, there is a 36 percent chance of a woman emerging as a candidate. When the chance of winning increases to just below 50 percent, the probability that a woman will emerge as a candidate increases to 75 percent.

This analysis highlights that women candidates are paying attention to the electoral context and are more likely to run in congressional districts where the electoral context affords them a greater opportunity to win. First, open-seat races represent the "best" opportunity for nonincumbents regardless of the candidate sex. Women with ambition for political office are more likely to emerge when there is an open seat. While women behave strategically by emerging in districts where they are more likely to win, women are still likely to emerge when the odds are not in their favor.

In addition to strategic behavior, the electoral opportunities available to women must represent a real opportunity of winning to increase women's representation. Where the maps in Figure 1 provide a snapshot of the electoral opportunities offered to women in 2014, Panel C and Panel D of Figure 2 are density plots of the probability of a woman winning for the entire dataset. While there are a handful of districts where the likelihood of a woman winning is very high, 
looking at these probabilities' distributions reveals the limited nature of women's electoral opportunities. If the elections were "gender-neutral"-meaning that, holding other factors constant, women and men would be equally likely to win-we would expect the mean and median of the probability distributions to be 0.5 , and the probabilities to be distributed normally around the mean. The vertical dashed lines in Panels $C$ and $D$ are at the 0.50 probability. By examining how these distributions differ from a normal distribution, we can see how gender shapes the electoral opportunities of women. The distributions for the probability of a woman winning the primary election (Panel C) and a woman winning the general election (Panel D) have means below 0.5 and are skewed to the left. This finding indicates that women are systematically less likely to win elected office than men. Even though women act strategically by choosing to run in elections where they are more likely to win, this does not mean they have an equal chance of winning. Women face an electoral map where the chances of winning are stacked against them. Thus, while women are emerging as candidates in districts where they are relatively likely to win, their chances of actually winning remain rather low.

Potential candidates should consider the probabilities of both winning the general election and winning the primary election, and emerge as candidates in districts where these probabilities are jointly the highest. I assess this claim by estimating candidate emergence as a function of the lagged probability of winning the primary, the lagged probability of winning the general, and an interaction between these two terms, along with the control variables described earlier. The third column of Table 2 reports coefficients for the probability of a woman winning the primary and the probability of a woman winning the general election. ${ }^{10}$

Panel A of Figure 3 presents the joint influence of the lagged probability of winning the primary election and the lagged probability of winning the general election on the probability of a woman candidate emerging in open-seat races. The bottom point in the center of Panel A represents the probability of a woman emerging as a candidate when the lagged probability of a woman winning the primary election and the lagged probability of a woman winning the general election are both 0 . Along the right-hand side, when moving away from the center, the lagged probability of winning the primary election increases. Along the left-hand side of the graph is the lagged probability of winning the general election, with the lagged probability increasing the further you move away from the center. The height of the graph depicts the probability of a woman emerging. The results in Figure 3 indicate that women are more likely to emerge as candidates as the probability of winning the primary and general elections increase. The same probabilities appear in Panels B and C, but the graph has been rotated to better illustrate the marginal effects of each constituent term of the interaction when the other constituent term is equal to 0 . In Panel $\mathrm{B}$, the edge of the plane appearing closest to us is the marginal effect of winning the primary on a woman candidate emerging. In Panel $\mathrm{C}$, the edge of the plane closest to us is the marginal effect of winning the general election on the probability of a woman candidate emerging. These figures highlight the importance of both the primary and general electoral opportunities for women candidate emergence.

Panel D of Figure 3 is a contour plot that illustrates the probability of a woman emerging as a candidate at different lagged probabilities of a woman winning the primary election ( $\mathrm{x}$-axis) and a woman winning the general election (y-axis). The lines show the probability of a woman candidate emerging at given lagged values of a woman winning the primary election and general election. For example, there is a 75 percent chance of a woman emerging as a candidate for values falling on the line labeled 0.75 . This finding nicely illustrates that as the probabilities of a woman candidate winning the primary and general elections increase, so does the probability of a woman emerging as a candidate. Panel D allows us to assess if women candidates weight the probabilities of winning the primary and general election in making their decision to emerge.

\footnotetext{
${ }^{10}$ The full set of results are reported in Table A1 in the Online Appendix.
} 

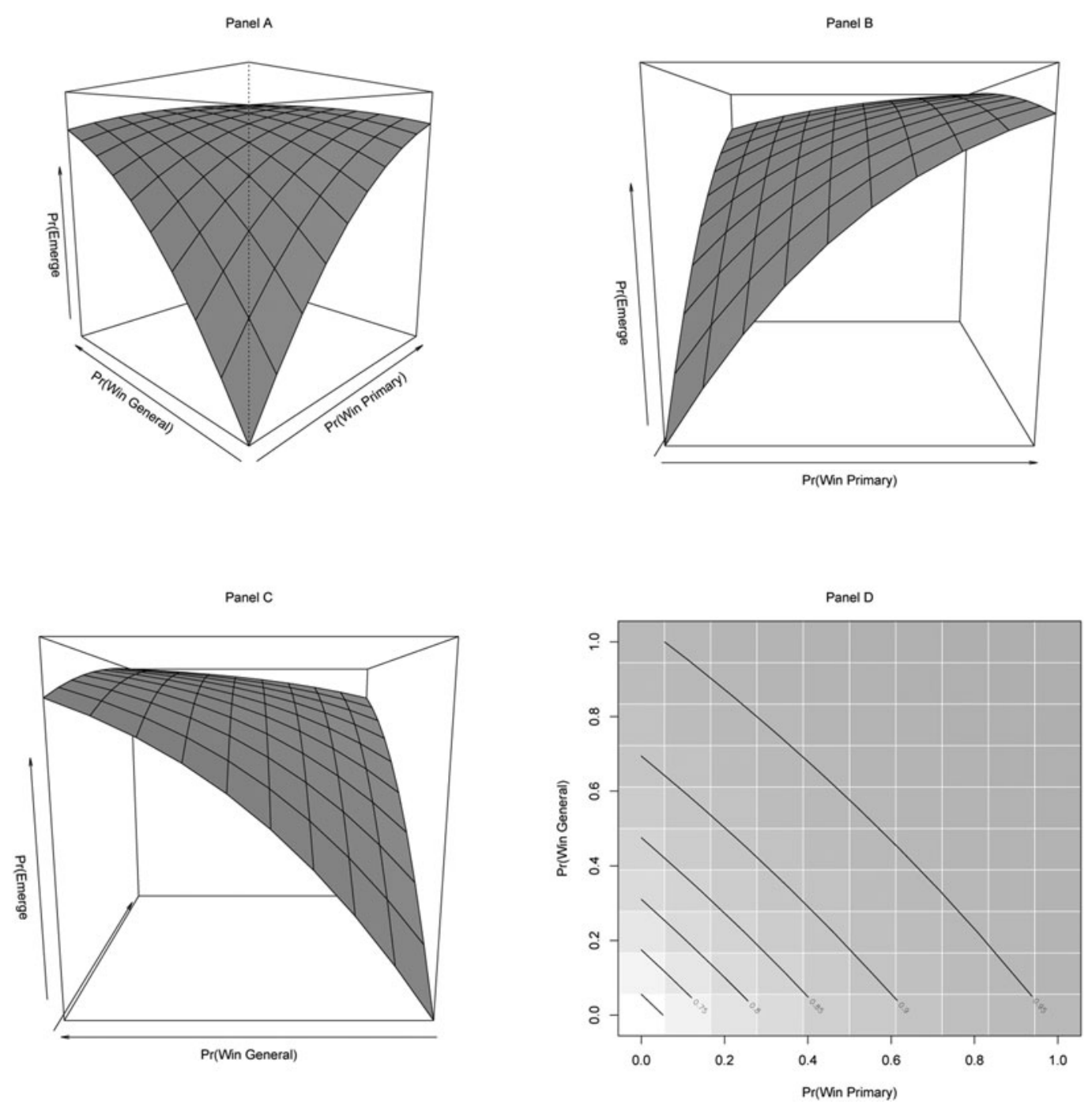

Figure 3. Joint relationship of a woman winning the primary and general elections on a woman emerging as a candidate.

The fairly straight diagonal lines indicate that the primary and general election contexts weigh about equally on a woman's decision to emerge.

If we consider a "general-neutral" election-where the probability of a woman winning is equal to a man (0.5) - how likely is it for a woman to emerge as a candidate? There is a probability of 0.84 that a woman will emerge as a candidate in a district when the likelihood of a woman winning the primary election equals 0.5 and the probability of a woman winning the general election is 0 . There is a probability of 0.85 of a woman emerging when the probability of a woman winning the general election is 0.5 and the probability of a woman winning the primary election is 0 . If the probability of a woman winning both the primary and general election is 0.5 , then the likelihood of a woman emerging increases to 0.93 .

The significance of interactions should not be directly assessed from the results reported in Table 2, and because the interaction consists of two continuous variables, interpretation and evaluating the significance of these effects is not straightforward (Brambor, Clark, and Golder 
Table 3. Results for Democratic and Republican candidates winning the primary election, winning the general election, and emerging as a candidate

\begin{tabular}{|c|c|c|c|}
\hline & $\begin{array}{l}\text { Emerge primary } \\
\text { (Primary) }\end{array}$ & $\begin{array}{l}\text { Emerge primary } \\
\text { (General) }\end{array}$ & $\begin{array}{c}\text { Emerge primary } \\
\text { (Interaction) }\end{array}$ \\
\hline \multicolumn{4}{|c|}{ Panel A: Democratic women } \\
\hline $\operatorname{Pr}(\text { Dem win primary })_{t-1}$ & $\begin{array}{l}4.14^{\star \star \star} \\
(0.21)\end{array}$ & - & $\begin{array}{l}1.54^{\star \star \star} \\
(0.28)\end{array}$ \\
\hline $\operatorname{Pr}(\text { Win general })_{t-1}$ & - & $\begin{array}{l}4.54^{\star \star} \\
(0.25)\end{array}$ & $\begin{array}{l}0.82 \\
(1.54)\end{array}$ \\
\hline Interaction & - & - & $\begin{array}{l}4.04^{\star \star \star} \\
(1.66)\end{array}$ \\
\hline \multicolumn{4}{|c|}{ Panel B: Republican women } \\
\hline $\operatorname{Pr}(\text { Rep win primary })_{t-1}$ & $\begin{array}{l}3.60^{\star \star \star} \\
(0.37)\end{array}$ & - & $\begin{array}{l}1.87^{\star \star \star} \\
(0.65)\end{array}$ \\
\hline $\operatorname{Pr}(\text { Rep win general })_{t-1}$ & - & $\begin{array}{l}3.89^{\star \star} \\
(0.27)\end{array}$ & $\begin{array}{l}3.75 \\
(0.33)\end{array}$ \\
\hline Interaction & - & - & $\begin{array}{l}-1.29 \\
(1.15)\end{array}$ \\
\hline
\end{tabular}

Notes: Bootstrapped coefficients and standard errors. Full model includes the following controls: incumbent; Democratic partisanship; Democratic vote ${ }_{t-1}$; woman senator; woman governor; percentage Democratic women in state legislature; percentage Republican women in state legislature; Democratic spending ${ }_{t-1}$; Republican spending ${ }_{t-1}$; type of primary dummies; percentage school-age children; percentage blue-collar workers; percentage four-year college graduates; percentage foreign born; percentage urban; relative income; land in square miles; percentage Hispanic; percentage black; South; and election dummies. ${ }^{*} p<0.1 ;{ }^{\star \star} p<0.05 ;{ }^{\star \star \star} p<0.01$.

2006). To assess the significance of these effects, Figure A1 in the Online Appendix reports the effect of women winning the primary at different values of women winning the general election, and Figure A2 in the Online Appendix reports the effect of women winning the general election at different values of women winning the primary election. The effect of the lagged probability of winning the primary election is significant when the probability of winning the general election is less than 0.8 . The lagged probability of winning the general election is significant at any level of winning the primary election. These results indicate that where women emerge as candidates is not random and women weigh the electoral opportunities in the primary and general elections about equally when making their decision to run. The next section assesses whether the same patterns hold when we analyze Democratic and Republican women separately.

The story of how electoral opportunities shape women's emergence becomes more complex when examining Democrats and Republicans separately. Starting with primary elections, the first column in Table 3 reports the coefficients for our variables of interest. ${ }^{11}$ Figure 4 depicts how the lagged probability of a woman winning the primary election shapes candidate emergence for Democrats (Panel A) and Republicans (Panel B). Again, predicted probabilities are plotted for open-seat elections (solid line) and non-open-seat elections (dotted line). Both Democratic and Republican women exhibit strategic behavior by emerging as candidates in primary elections where women are more likely to win. There is a 44 percent chance that a Democratic woman will emerge as a candidate (Panel A, solid line) when there is an open seat in districts with a low probability of a Democratic woman winning. When the probability of a Democratic woman winning increases to just below 50 percent, the probability of a Democratic woman emerging increases to 0.84 . When there is an incumbent running in the district (Panel A, dotted line), there is only a 14 percent chance of a woman Democrat emerging as a candidate when the chances that she wins the primary is less than 2 percent. When the chance that a Democratic woman wins the primary increases to just below 50 percent, the probability that a woman Democrat emerges as a candidate increases to 0.52. Similar to women Democrats, women Republicans in open-seat races with less than a 2 percent chance of winning have a probability of 0.40 of emerging as a candidate. However, the relationship between winning and emerging

\footnotetext{
${ }^{11}$ For the full model results, see Tables A2 and A3 in the Online Appendix.
} 


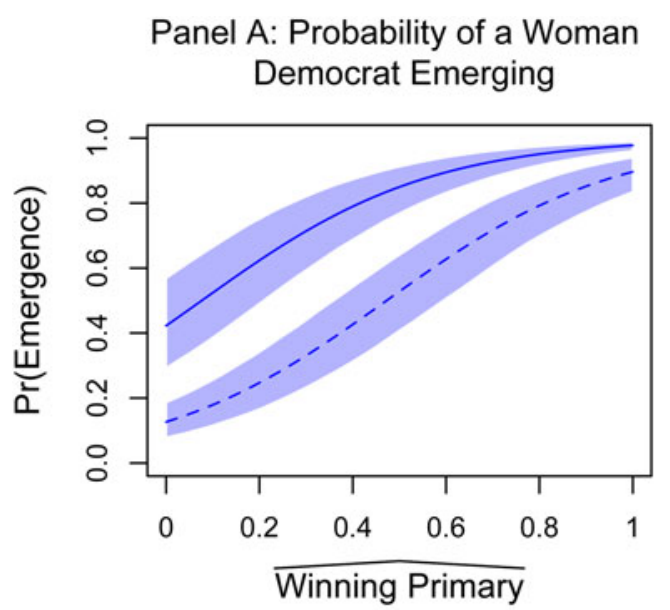

Panel C: Probability of a Woman Democrat Winning Primary

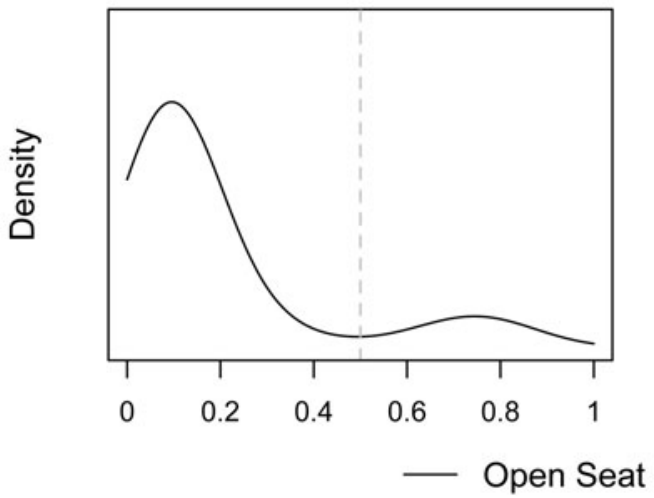

Panel B: Probability of a Woman Republican Emerging

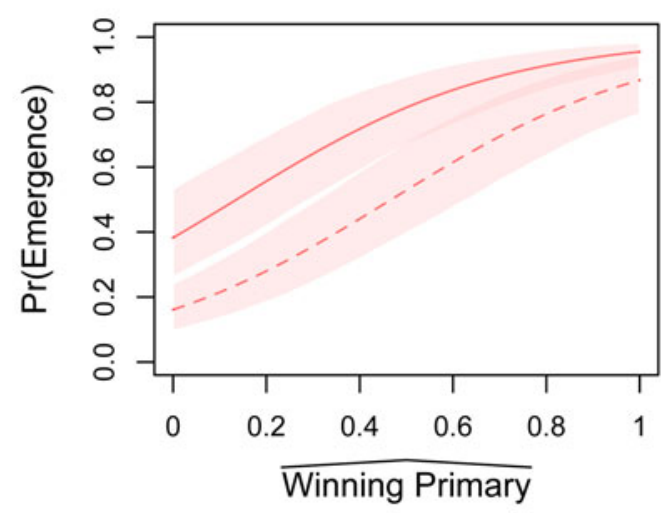

Panel D: Probability of a Woman Republican Winning Primary

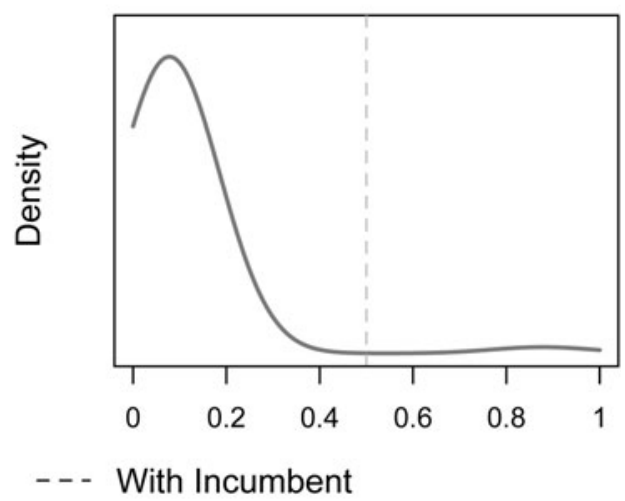

Figure 4. Predicted probabilities of a woman candidate emerging in the primary election and distributions of the probabilities of a woman winning the primary election by party.

in the primary is steeper for Republican women than it is for Democratic women. When there is about a 50 percent chance of a Republican woman winning, the probability that a Republican woman will emerge increases to 0.78 . When there is an incumbent running and it is unlikely that a Republican woman will win the primary, the probability that a Republican woman well emerge drops to 0.17 . In districts with an incumbent and just below a 50 percent chance of a Republican woman winning, the chance of a Republican woman emerging increases to 52 percent.

The density plots in Panel C and Panel D of Figure 4 further illustrate the considerable difference in opportunities available to Democratic and Republican women. The mean probability that a woman will win a primary election is considerably less than 0.5 for Democratic and Republican women. The distributions skew to the left, indicating that, on average, women are electorally disadvantaged. The mean of a Democratic woman winning the primary is 0.19 , which is almost twice as high as the mean probability of a Republican woman winning the primary (0.10). At the mean likelihood of victory for Democratic women, there is just over a 0.5 chance that a woman will emerge as a candidate. When the likelihood of a Republican winning is at the 
Panel A: Probability of a Democratic Woman Emerging

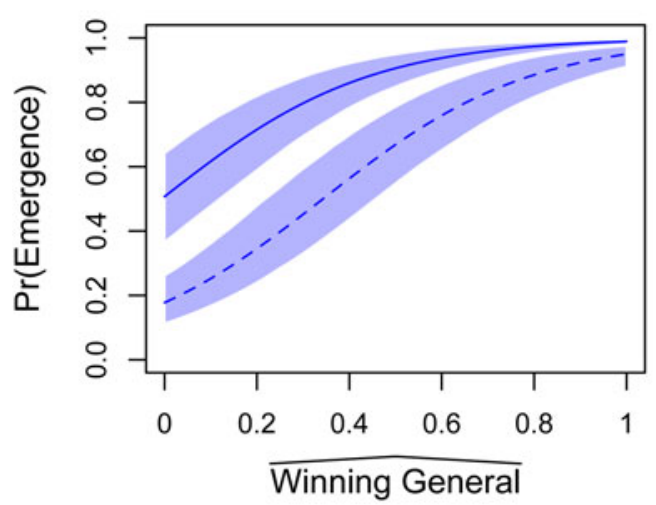

Pancel C: Probability of Woman Democratic Woman Winning General

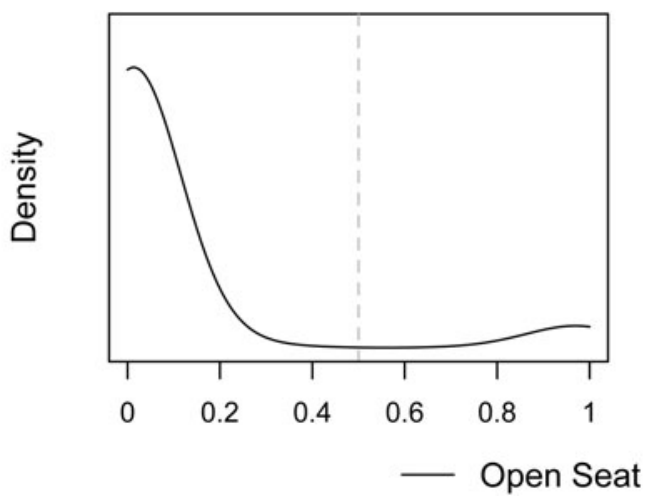

Panel B: Probability of a Republican Woman Emerging

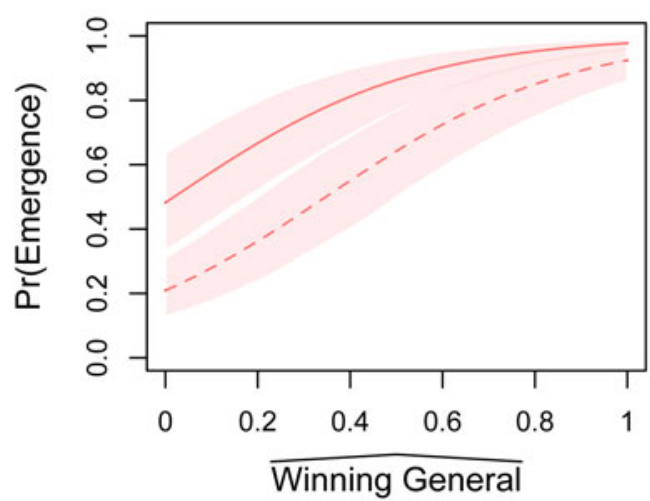

D: Probability of Woman Republican Woman Winning General

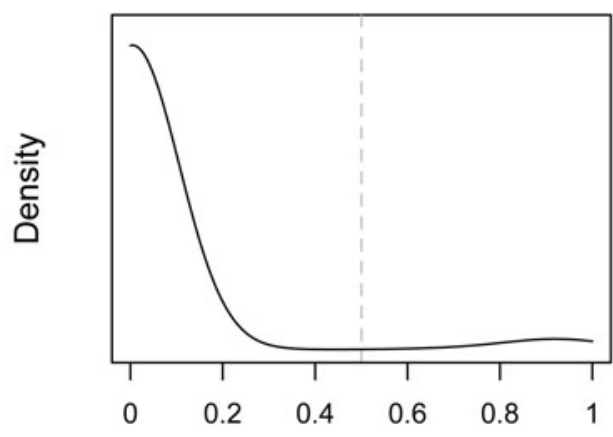

- - With Incumbent

Figure 5. Predicted probabilities of a woman candidate emerging in the primary election and distributions of the probabilities of a woman winning the general election by party.

mean, there is a 0.3 chance of a woman emerging as a candidate. Thus, despite their strategic behavior, the electoral opportunities result in Democratic women and Republican women emerging in elections where their chance of winning are relatively low.

Turning to the general election, Figure 5 illustrates how the probability of winning the general election shapes the emergence of a Democratic woman (Panel A) and a Republican woman candidate (Panel B). Democratic and Republican women continue to engage in strategic behavior by emerging in races where they have a higher chance of winning the general election. In the most hostile districts with open seats (solid lines), there is about a 53 percent chance of a Democratic woman emerging and 50 percent chance of a Republican woman emerging as a candidate. When the chance of winning increases to about 50 percent, the probability of a Democratic woman emerging increases to 0.9 and the probability of a Republican woman emerging increases to 0.87 . When an incumbent is present and there is a low chance of winning the general election (dotted line), the probability of a Democratic women emerging is 0.19 and the probability of a Republican woman emerging is 0.20 . When the chances of a woman winning in the general election increase to about 50 percent with an incumbent present, the chances of a Democratic woman emerging increase to 60 percent and the chances of a Republican woman emerging increase to 
63 percent. When just considering the general election, Democratic and Republican women are both relatively likely to throw their hats into the ring, even when their chance of winning is rather low.

The difference between the electoral opportunities available to Democratic women and Republican women can explain why there is such a partisan imbalance of women in elected office. How party affiliation shapes electoral opportunities can be seen by comparing the distributions of the probability of a Democratic woman winning the general election and a Republican woman winning the general election (Panels $\mathrm{C}$ and $\mathrm{D}$ of Figure 5). The mean probability of a Democratic woman succeeding in the general election is 0.10 , which is more than twice as high as that of a Republican woman winning the general election (0.05). At their respective means, there is a 0.59 probability of a Democratic woman emerging as a candidate and a 0.35 probability of a Republican woman emerging as a candidate.

I assess whether my general findings about emergence hold for both parties by estimating models with the lagged probability of a woman winning the primary, the lagged probability of a woman winning the general election, and an interaction between the two variables for Democratic women and Republican women. ${ }^{12}$ Figure 6 illustrates the interactive relationship for Democratic women and Figure 7 shows the interactive relationship for Republican women.

The results for Democratic women look similar to the results for all candidates. Panels A, B, and $C$ in Figure 6 plot the probability of emerging in three dimensions. Panel B rotates the figure so that the edge of the plane closest to us is the marginal effect of winning the primary on emerging when the lagged probability of winning the general election is 0 . As the lagged probability of a Democratic woman winning the primary increases, so does the probability that a woman Democrat will emerge. Panel C performs a similar rotation, with the edge closest to us being the marginal effect of winning the general election when the lagged probability of winning the primary is 0 . Once again, the probability of a Democratic woman emerging increases as the probability of a Democratic woman winning the general election increases.

Panel D of Figure 6 is a contour plot that helps us further understand the relationship between expected primary and general election success and a Democratic woman emerging. If we consider a "gender-neutral" election where the probability of winning the primary election is 0.5 and the probability of winning the general election is 0 , the probability that a woman Democrat will emerge as a candidate is 0.57 . When the probability of winning the general election is 0.5 and the probability of winning the primary is 0 , the probability that a woman Democrat will emerge as a candidate is 0.51 . However, when the probabilities of winning both the general and the primary elections are 0.5 , the probability that a woman Democrat will emerge as a candidate is 0.81 . Looking at a "gender-neutral" election overlooks an interesting pattern in Panel D. The concave curves suggest a positive interaction between the probabilities of winning in the primary election and winning in the general election. The probabilities of winning the primary and winning the general elections are weighted about equally in Democratic women's decision to emerge as a candidate.

Due to the difficulty in assessing the significance of an interaction with two continuous variables, I present the effects of each variable plotted against different levels of the other variable. Figure A3 in the Online Appendix reports the effect of women winning the primary at different values of women winning the general election. The probability of winning the primary is statistically significant for all values of the probability of winning the general election. Figure A4 in the Online Appendix reports the effect of women winning the general election at different values of women winning the primary election. The effect of the probability of winning the general election is significant for all but the lowest values of the probability of winning the primary election.

We see a similar story in the relationship between the likelihood of wining the primary and general elections for Republican women. Panels A, B, and C of Figure 7 are three-dimensional

\footnotetext{
${ }^{12}$ Tables A2 and A3 in the Online Appendix report the full results for these models.
} 

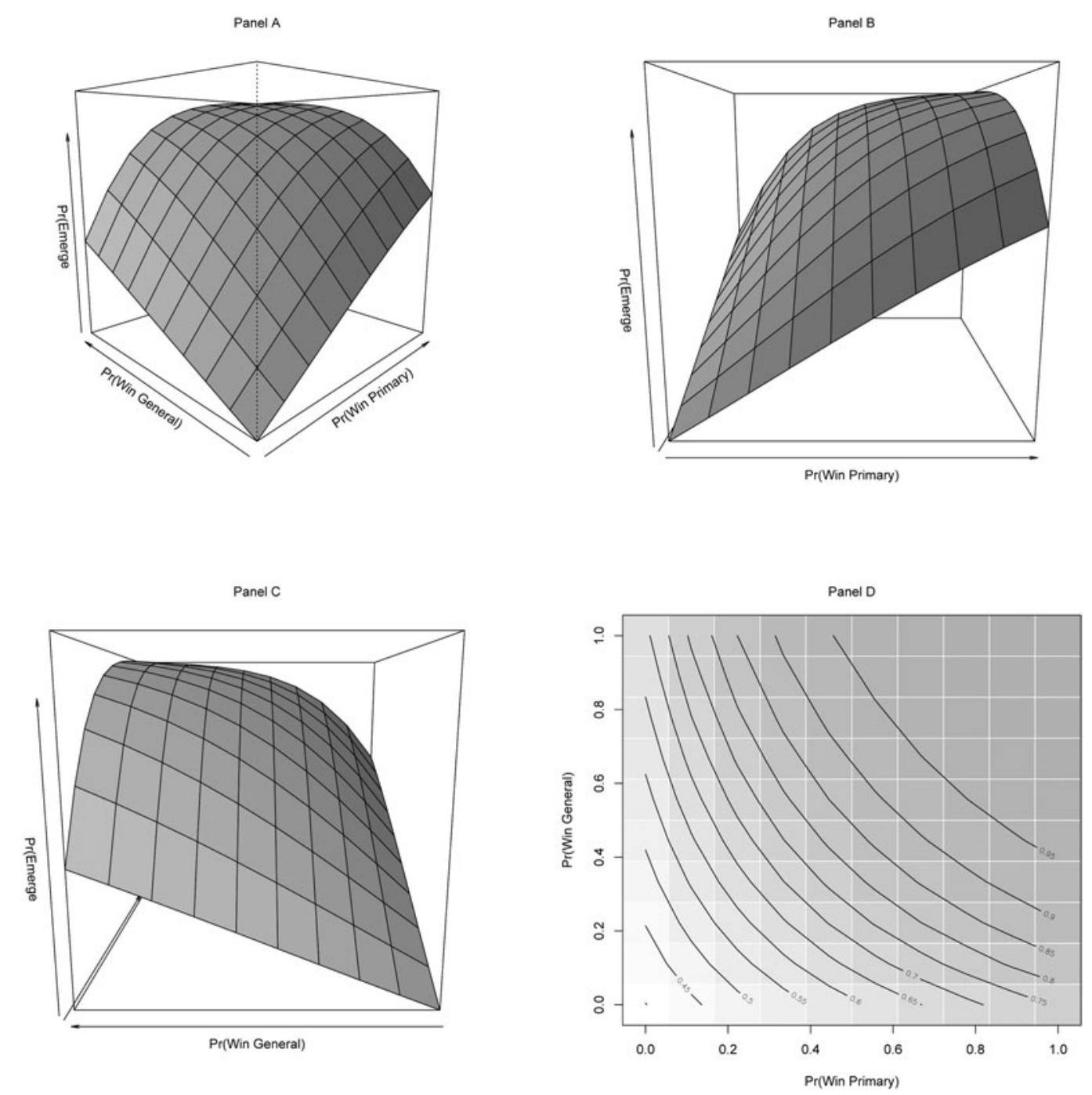

Figure 6. Joint effects of a Democratic woman winning the primary and general elections on a woman emerging as a candidate.

plots of the probability of a Republican woman emerging at different values of the lagged probability of a Republican woman winning the primary election and the lagged probability of a Republican woman winning the general election. Panel B rotates the figure, with the edge of the plane closest to us representing the marginal effect of winning the primary when the lagged probability of winning the general election equals 0 . Panel $C$ is another rotation, with the edge closest to us depicting the marginal effect of winning the general election when the lagged probability of winning the primary election equals 0 . Panels $A$ and $B$ highlight that as the lagged probability of winning the primary election increases, the likelihood of a Republican woman emerging increases. Panels A and C highlight a similar relationship between winning the general election and emerging. The downward slope of the plane between the probabilities of winning the general election and winning the primary election suggests the likelihood of winning the general election is weighted heavier in Republican women's decision to emerge than the likelihood of winning the primary. 

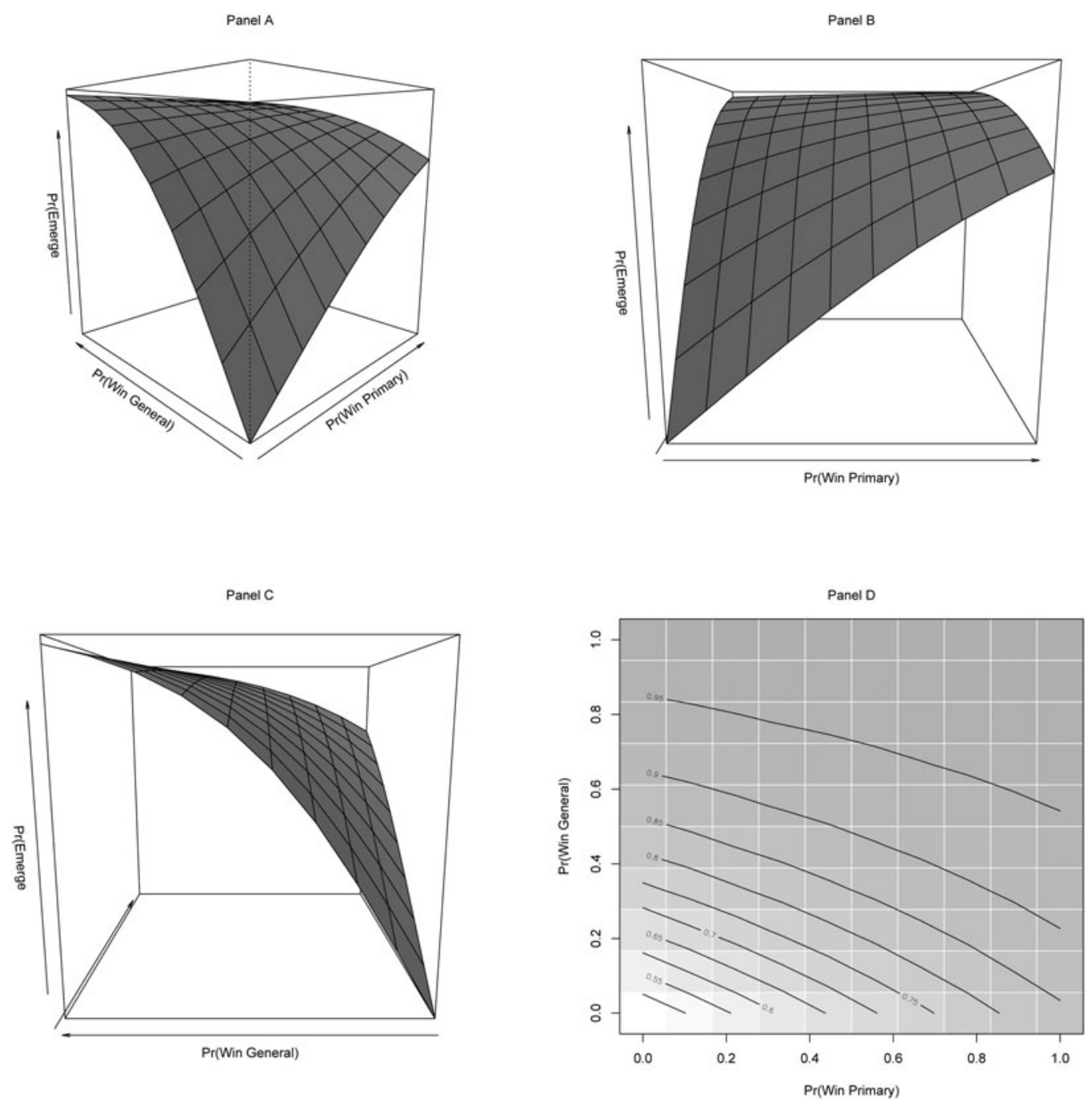

Figure 7. Joint effects of a Republican woman winning the primary and general elections on a woman emerging as a candidate.

Panel D is a contour plot of the probability of a Republican woman emerging (lines) at different levels of the lagged probability of winning the primary election (x-axis) and winning the general election (y-axis). Again, consider a gender-neutral election where a Republican woman has the same 0.5 chance of winning as a Republican man. If the lagged probability of winning the primary election is 0.5 and the lagged probability of winning the general election is 0 , the probability that a Republican woman will emerge as a candidate is 0.65 . If the lagged probability of winning the general election is 0.5 and the lagged probability of winning the primary election is 0 , the probability that a Republican woman will emerge as a candidate is 0.81 . However, if a Republican woman's lagged probability of winning both the primary and general election is 0.5 , the probability of a Republican woman emerging as a candidate increases to 0.90 .

To assess the significance of the variables in the interaction, I plotted the effects of each variable over the range of values for the other variable. The lagged probability of winning the primary election is significantly related to where Republican women emerge as candidates when values of 
the lagged probability of winning the primary election are at or below 0.6 (see Figure A5 in the Online Appendix). The lagged probability of winning the general election is significantly related to the decision of where to emerge as a candidate at all the lagged probabilities of winning the primary election (see Figure A6 in the Online Appendix).

\section{Conclusion}

While many scholars have argued women candidates make careful calculations about where and when to run for elected office, these studies reach this conclusion by examining a variety of indirect indicators of strategic behavior. My analyses test the claim that women act strategically by entering into races where they have a higher probability of winning. My findings suggest that where women run and win is nonrandom and, consequently, that the observational results underlying the claim that "when women run, they win" are most likely driven by when and where women choose to run. Women continue to face gendered electoral opportunities, limiting their ability to advance their numbers in elected office. As a result, strategic behavior is a necessary but not sufficient condition for increasing women's representation in Congress.

Over the past several decades, we have seen a growing gap between the number of women Democrats running and being elected and the number of Republican women running and being elected. Looking separately at the behavior of Democrats and Republicans helps us understand why this partisan imblance is the case. The electoral opportunities for Republican women are much more limited. For both the primary and general elections, Republican women have a much lower probability of winning than Democratic women. There are slight differences in how Democratic and Republican women consider the probability of winning the primary and general elections when deciding to emerge as candidates. Democratic women weigh their chances in the primary election and the general election about equally, emerging in districts where they are more likely to win both competitions. Republican women place greater weight on their ability to win the general election than the primary. Changes in the Republican Party may make the opportunities for women candidates even more narrow in the future (Thomsen 2015).

The results reported here have important implications for the study of women's electoral success. The increasing number of women candidates led to extensive research on the barriers that women may face in electoral settings versus laboratory settings (Dolan 2014; Hayes and Lawless 2015). My results suggest we should be cautious not to overinterpret the findings that gender stereotypes are diminishing and have a limited effect on electoral outcomes. While voters do not universally use gender stereotypes to evaluate all women candidates, the strategic behavior of potential women candidates indicates that women are aware that their chances of winning are not consistent across all congressional districts. These results are consistent with research that finds gender stereotypes continue to act as a barrier to women in elected office, and help reconcile the differences between observational and empirical research (Bauer 2015; Ditonto 2017; Schneider and Bos 2014).

Women's underrepresentation in elected office is commonly framed as a problem of either supply or demand (Crowder-Meyer 2013; Karpowitz, Quin Monson, and Preece 2017). On the supply side, such factors as resources, interest, ability, aspiration, and self-perception shape the potential pool of candidates. The demand for women candidates is shaped by voter bias, institutions, and gatekeepers. While this framework has been beneficial in helping think about the multiple mechanisms that may shape women's underrepresentation, it fails to account for the way that supply and demand may interact and be shaped by context. If faced with poor electoral opportunities, women candidates may fail to emerge even if they have the resources, interest, or aspiration. Additionally, context is likely to shape the decision making of parties and other gatekeepers about where they should encourage women candidates by investing their time and resources. 
Moreover, context is dynamic. Changes in the composition of congressional districts and parties will continue to evolve to shape women's electoral opportunities and their decision to emerge as candidates. The 2018 and 2020 elections saw a record number of women run and win elected office. Both elections highlight the importance of location in the success of women in elected office. Progress toward parity will be slow as a result of the uneven geography of women emerging and succeeding. These elections further illustrate the importance of party affiliation in shaping women's electoral opportunities. In 2018, the increased representation of women was driven by Democratic women. In contrast, Republican women were largely responsible for the increased number of women in elected office in 2020. The hurdles women face vary not only by location, but also by the stage of the election and by the party. These obstacles are most likely the result of a complex interaction between voters' attitudes and party gatekeepers, which shape the expression of political ambition among women. While research has examined both voters' attitudes toward women candidates (Ditonto 2017; Schneider and Bos 2014) and the role of party gatekeepers (Butler and Preece 2016), further research is needed to understand how their interaction conditions the political ambition and success of women candidates.

Supplementary Material. Online appendices are available at: https://doi.org/10.1017/S0007123421000508

Data Availability Statement. Replication data files can be found in Harvard Dataverse at: https://doi.org/10.7910/DVN/ OAJIY

Acknowledgments. I would like to thank the members of the Gender and Political Writing Group, Susan Welch, Kira Sanbamantsu, Mirya Holman, Erin Cassese, Danielle Thomsen, Jessica Preece, Rosalyn Cooperman Korff, Melody Crowder-Meyer, Jason Windett, Ellen Key, Adam Newmark, Will Hicks, and Jeff Carter for feedback on the manuscript. Special thanks to Chuck, Edie, Manny, and Miss Bee for use of the lake house, where substantial portions of this manuscript were drafted and revised.

Financial Support. None.

Competing Interests. None.

\section{References}

Anzia SF and Berry CR (2011) The Jackie (and Jill) Robinson effect: why do congresswomen outperform congressmen? American Journal of Political Science 55(3), 478-493.

Barnes TD, Branton RP and Cassese EC (2017) A reexamination of women's electoral success in open seat elections: the conditioning effect of electoral competition. Journal of Women, Politics \& Policy 38(3), 298-317.

Bauer NM (2015) Emotional, sensitive, and unfit for office? Gender stereotype activation and support female candidates. Political Psychology 36(6), 691-708.

Bauer NM (2020) Shifting standards: how voters evaluate the qualifications of female and male candidates. The Journal of Politics 82(1), 1-12.

Bernhard R, Shames S, and Teele DL (2021) To emerge? Breadwinning, motherhood, and women's decisions to run for office. American Political Science Review 115(2), 379-394.

Brambor T, Clark WR, and Golder M (2006) Understanding interaction models: improving empirical analyses. Political Analysis 14(1), 63-82.

Burrell B (2014) Gender in Campaigns for the U.S. House of Representatives. Ann Arbor, MI: University of Michigan Press.

Butler DM and Preece JR (2016) Recruitment and perceptions of gender bias in party leader support. Political Research Quarterly 69(4), 842-851.

Cameron AC and Trivedi PK (2005) Microeconometrics: Methods and Applications. New York, NY: Cambridge University Press.

Carroll SJ and Sanbonmatsu K (2013) More Women Can Run: Gender and Pathways to the State Legislatures. New York, NY: Oxford University Press.

Crespin MH and Deitz JL (2010) If you can't join 'em, beat 'em: the gender gap in individual donations to congressional candidates. Political Research Quarterly 63(3), 581-593.

Crowder-Meyer M (2013) Gendered recruitment without trying: how local party recruiters affect women's representation. Politics \& Gender 9, 390-413.

Crowder-Meyer M and Cooperman R (2018) Can't buy them love: how party culture among donors contributes to the party gap in women's representation. The Journal of Politics 80(4), 1211-1224. 
Crowder-Meyer M and Lauderdale B (2014) A partisan gap in the supply of female potential candidates in the United States. Research and Politics 1(1), 1-7.

Ditonto T (2017) A high bar or a double standard? Gender, competence, and information in political campaigns. Political Behavior 39(2), 301-325.

Dittmar K (2015) Navigating Gendered Terrain: Stereotypes and Strategy in Political Campaigns. Philadelphia, PA: Temple University Press.

Dittmar K (2021) Measuring Success: Women in 2020 Legislative Elections. Technical report, Eagleton Institute of Politics, Rutgers University, New Brunswick, NJ, USA.

Dolan K (2014) When Does Gender Matter? Women Candidates and Gender Stereotypes in American Elections. New York, NY: Oxford University Press.

Fiber-Ostrow P (2012) Opening the door: women candidates and California's primary elections. Journal of Women, Politics \& Policy 33(1), 1-24.

Fulton SA (2012) Running backwards and in high heels the gendered quality gap and incumbent electoral success. Political Research Quarterly 65(2), 303-314.

Fulton SA et al. (2006) The sense of a woman: gender, ambition, and the decision to run for Congress. Political Research Quarterly 59(2), 235-248.

Hayes D and Lawless JL (2015) A non-gendered lens: the absence of stereotyping in contemporary congressional elections. Perspectives on Politics 13(1), 95-118.

Herrick R (1996) Is there a gender gap in the value of campaign resources? American Politics Quarterly 24(1), 68-80.

Hoffman KU, Palmer C, and Gaddie RK (2001) Candidate sex and congressional elections: open seats before, during, and after the year of the woman. Women \& Politics 23(1-2), 37-58.

Kanthak K and Woon J (2015) Women don't run? Election aversion and candidate entry. American Journal of Political Science 59(3), 595-612.

Karpowitz CF, Quin Monson J, and Preece JR (2017) How to elect more women: gender and candidate success in a field experiment. American Journal of Political Science 61(4), 927-943.

Lawless JL and Fox RL (2010) It Still Takes a Candidate: Why Women Don't Run for Office. New York, NY: Cambridge University Press.

Lawless JL and Pearson K (2008) The primary reason for women's underrepresentation? Reevaluating the conventional wisdom. The Journal of Politics 70(1), 67-82.

Lazarus J (2008) Buying in: testing the rational model of candidate entry. The Journal of Politics 70(3), 837-850.

Ondercin H (2022) "Replication Data for: Location, Location, Location: How Electoral Opportunities Shape Women's Emergence as Candidates”, https://doi.org/10.7910/DVN/OAJJIY, Harvard Dataverse, V1.

Ondercin $\mathbf{H}$ and Welch S (2005) Women candidates for Congress. In Thomas S and Wilcox C (eds) Women and Elective Office: Past, Present, and Future. Oxford: Oxford University Press, pp. 60-80.

Palmer B and Simon D (2010) Breaking the Political Glass Ceiling: Women and Congressional Elections. New York, NY: Routledge.

Pearson K and McGhee E (2013) What it takes to win: questioning "gender neutral" outcomes in US House elections. Politics \& Gender 9(4), 439.

Preece J and Stoddard O (2015) Why women don't run: experimental evidence on gender differences in political competition aversion. Journal of Economic Behavior \& Organization 117, 296-308.

Sanbonmatsu K (2010) Where Women run: Gender and Party in the American States. Ann Arbor, MI: University of Michigan Press.

Schneider MC and Bos AL (2014) Measuring stereotypes of female politicians. Political Psychology 35(2), 245-266.

Schneider MC et al. (2016) Power, conflict, and community: how gendered views of political power influence women's political ambition. Political Psychology 37(4), 515-531.

Shames SL (2017) Out of the Running: Why Millennials Reject Political Careers and Why It Matters. New York, NY: NYU Press.

Stone WJ and Maisel LS (2003) The not-so-simple calculus of winning: potential US House candidates' nomination and general election prospects. Journal of Politics 65(4), 951-977.

Stone WJ, Maisel LS and Maestas CD (2004) Quality counts: extending the strategic politician model of incumbent deterrence. American Journal of Political Science 48(3), 479-495.

Thomsen DM (2015) Why so few (Republican) women? Explaining the partisan imbalance of women in the US Congress. Legislative Studies Quarterly 40(2), 295-323.

Thomsen DM and Swers ML (2017) Which women can run? Gender, partisanship, and candidate donor networks. Political Research Quarterly 70(2), 449-463.

Cite this article: Ondercin HL (2022). Location, Location, Location: How Electoral Opportunities Shape Women's Emergence as Candidates. British Journal of Political Science 52, 1523-1543. https://doi.org/10.1017/S0007123421000508 